\title{
Histamine Released from Epidermal Keratinocytes Plays a Role in $\alpha$-Melanocyte-Stimulating Hormone-Induced Itching in Mice
}

\author{
Kyoko Shimizu, ${ }^{*}$ Tsugunobu Andoh, ${ }^{\dagger}$ Yoko Yoshihisa, ${ }^{*}$ and Tadamichi Shimizu*
}

From the Departments of Dermatology* and Applied Pharmacology, ${ }^{\dagger}$ Graduate School of Medicine and Pharmaceutical Sciences, University of Toyama, Toyama, Japan

\author{
Accepted for publication \\ July 14, 2015. \\ Address correspondence to \\ Tadamichi Shimizu, M.D., \\ Ph.D., Department of Derma- \\ tology, Graduate School of \\ Medicine and Pharmaceutical \\ Sciences, University of \\ Toyama, 2630 Sugitani, \\ Toyama, Japan. E-mail: \\ shimizut@med.u-toyama.ac.jp.
}

\begin{abstract}
Sunburn, wound repair, and chronic renal failure with hemodialysis are usually accompanied by both pigmentation and itching. Proopiomelanocortin-derived $\alpha$-melanocyte-stimulating hormone $(\alpha-\mathrm{MSH})$ is produced in response to external stimuli, such as UV irradiation, and is involved in cutaneous pigmentation. However, it is unclear whether $\alpha-M S H$ is also involved in the itching. We therefore investigated whether $\alpha$-MSH elicited itch-related responses in mice. We found that an intradermal injection of $\alpha$-MSH induced hind-paw scratching, an itch-related response, in mice. The $\alpha-\mathrm{MSH}-$ induced scratching was inhibited by the $\mu$-opioid receptor antagonist naltrexone and the $\mathrm{H}_{1}$ histamine receptor antagonist terfenadine. In mast cell-deficient mice, $\alpha$-MSH also elicited scratching, which was inhibited by terfenadine. The immunoreactivity for L-histidine decarboxylase, a key enzyme required for the production of histamine, histamine, and the melanocortin 1 and 5 receptors were shown in not only mast cells but also keratinocytes in murine skin. In addition to the expression of L-histidine decarboxylase and melanocortin 1 and 5 receptors, the mouse keratinocyte cell lines (Pam212) also showed immunoreactivity for L-histidine decarboxylase, histamine, and melanocortin 1 and 5 receptors. The application of $\alpha$-MSH induced the release of histamine from Pam212 cells. These findings indicate that $\alpha$-MSH may play an important role in the itching associated with pigmented cutaneous lesions and that the histamine released from keratinocytes is involved in this $\alpha-\mathrm{MSH}$-induced itching. (Am J Pathol 2015, 185: 3003-3010; http://dx.doi.org/10.1016/j.ajpath.2015.07.015)
\end{abstract}

Itch is an unpleasant sensation associated with the immediate desire to scratch, thereby making the cutaneous symptoms worse. Several skin and general conditions are associated with both pigmentation and itch. In addition, itch associated with sunburn is widely recognized to be the result of an inflammatory reaction to UV irradiation, which increases the amount of itch and erythema, after which the healing process results in later skin pigmentation. ${ }^{1}$ Gilchrest et al $^{2}$ reported that the histamine level rises immediately after the onset of UV-induced erythema. Itch and cutaneous pigmentation also occur in association with chronic wounds and hypertrophic scars. Paul ${ }^{3}$ noted that wound-related itch is more frequently observed in patients with severe wounds. Itch may also be caused by dry skin or serious internal diseases, such as chronic renal failure that requires hemodialysis, which is usually accompanied by cutaneous pigmentation. Taken together, it is still unclear if the underlying mechanisms of itch in these pruritic diseases involve the interaction between cutaneous pigmentation and itch.

$\alpha$-Melanocyte-stimulating hormone $(\alpha-\mathrm{MSH})$ is one of the neuropeptides that is generated through the cleavage of a precursor protein called proopiomelanocortin, which is produced through the production of corticotropin-releasing hormone, also known as corticotropin-releasing factor, after various stressors, such as UV irradiation. ${ }^{4-7} \alpha-\mathrm{MSH}$ receptors are known as melanocortin receptors (MC1R, MC3R, MC4R, and MC5R). ${ }^{4}$ These receptors belong to the

\footnotetext{
Supported by the Japanese Ministry of Health, Labor and Welfare grant H24-007 (T.A.) and Japan Society for the Promotion of Science grants-inaid for scientific research 25460717 (T.A.) and 25860938 (Y.Y.).

Disclosures: None declared.
} 
G protein-coupled receptor family, and the activation of these receptors increases the production of cAMP. ${ }^{8}$ In addition, it was also reported that $\alpha$-MSH increases intracellular-free $\mathrm{Ca}^{2+}$ concentration in human embryonic kidney cells that express these melanocortin receptors. ${ }^{9}$ In the skin, MC1R and MC5R are mainly expressed. ${ }^{10} \alpha$-MSH produced by external stimuli, such as UV irradiation, induces cutaneous pigmentation through the activation of MC1R. ${ }^{4,6,7,10,11} \alpha$-MSH is also increased in plasma of patients with chronic hemodialysis ${ }^{12}$ and in epidermal keratinocytes during cutaneous wound repair. ${ }^{13}$ However, no previous reports indicate whether $\alpha-\mathrm{MSH}$ is also involved in the itching that results from these factors.

Here, we investigated whether $\alpha$-MSH elicited itch in mice. Furthermore, we performed a series of experiments to elucidate the mechanism underlying the development of $\alpha$-MSH-induced itch, focusing on the involvement of histamine, which is known to play an important role in the pathogenesis of itch.

\section{Materials and Methods}

\section{Animals}

Male ICR mice (4 to 9 weeks old), mast cell-deficient WBB6F1 $W / W^{\nu}$ (6 to 9 weeks old), and the normal littermates $\left(\mathrm{WBB} 6 \mathrm{~F}^{+/+}{ }^{+}, 6\right.$ to 9 weeks old) were used in this study. These mice were purchased from Japan SLC (Hamamatsu, Japan). They were housed in a room with controlled temperature $\left(21^{\circ} \mathrm{C}\right.$ to $23^{\circ} \mathrm{C}$ ), humidity (45\% to $65 \%$ ), and light (7:00 AM to 7:00 PM) conditions. Food and water were available ad libitum. Procedures for animal experiments were approved by the Committee for Animal Experiments at the University of Toyama.

\section{Cell Culture and siRNA Treatment}

The murine epidermal cell line (Pam212) was cultured in Dulbecco's modified Eagle's medium (Invitrogen, Carlsbad, CA) supplemented with $10 \%$ fetal bovine serum, $100 \mathrm{U} / \mathrm{mL}$ penicillin, and $100 \mu \mathrm{g} / \mathrm{mL}$ streptomycin under standard cell culture conditions $\left(37^{\circ} \mathrm{C}, 5 \% \mathrm{CO}_{2}\right.$ in a humidified incubator).

In a part of the experiment, siRNA-treated cells were used. siRNAs as a control, MC1R and MC5R, were purchased from Santa Cruz Biotechnology, Inc. (Santa Cruz, CA). These siRNAs were transfected with Lipofectamin RNAi MAX reagent (Life Technologies, Carlsbad, CA). The transfection was performed according to the manufacturer's protocol (Life Technologies).

\section{Agents}

$\alpha$-MSH was purchased from Peptide Institute, Inc. (Osaka, Japan). For in vivo experiments, $\alpha$-MSH was dissolved in physiologic saline and was injected intradermally in a volume of $50 \mu \mathrm{L}$ into the rostral skin of mice. For in vitro experiments,
$\alpha$-MSH was dissolved in Opti-MEM (Thermo Fisher Scientific Inc., Waltham, MA). Naltrexone hydrochloride (SigmaAldrich, St. Louis, MO) was dissolved in physiologic saline and injected subcutaneously 15 minutes before $\alpha$-MSH injection. Terfenadine (Sigma-Aldrich) was suspended in $0.5 \%$ sodium carboxy methylcellulose (Wako Pure Chemical Industries, Ltd., Osaka, Japan) and was administered 30 minutes before $\alpha$-MSH injection. SQ 22,536 (Tocris Bioscience, Bristol, UK) and EGTA (Dojindo Laboratories, Kumamoto, Japan) were dissolved in dimethyl sulfoxide and diluted with Opti-MEM (final concentration dimethyl sulfoxide, $0.1 \%$ ). These agents were treated 30 minutes before the application of $\alpha-\mathrm{MSH}$.

\section{Behavioral Experiments}

The day before the experiment, the hair was clipped over the rostral part of the mouse back. Before behavioral observation, the animals were placed individually in an acrylic cage composed of four compartments $(13 \times 9 \times 35 \mathrm{~cm})$ for at least 1 hour for acclimation. Immediately after intradermal injection, mice were put back into the same cells, and their behaviors were recorded with the use of a digital video camera (HDC-TM25; Panasonic Co., Osaka, Japan) for 1 hour with personnel kept out of the observation room. Playback of the digital recording allowed for counting of injection site scratching by the hind paw. The series of movements scratched several times for about 1 second were considered as one bout of scratching. ${ }^{14}$

\section{Immunostaining}

Under anesthesia with pentobarbital $(80 \mathrm{mg} / \mathrm{kg}$, intraperitoneal), mice were transcardially perfused with phosphatebuffered saline (PBS) and then 4\% paraformaldehyde. The skin of the rostral back was isolated, postfixed with $4 \%$ paraformaldehyde, and immersed in 30\% sucrose solution for 2 days. The tissue was embedded in Tissue-Tek O.C.T. Compound (Sakura Fineteck Co., Ltd., Tokyo, Japan) and kept at $-80^{\circ} \mathrm{C}$ until use. The frozen samples were sectioned at $20 \mu \mathrm{m}$ with a cryostat (Leica, Wetzlar, Germany). In the keratinocyte cell line Pam212, cells cultured on glass-bottomed dishes were washed twice with PBS and fixed with $4 \%$ paraformaldehyde. After being washed three times with PBS, the sections or cells were treated with $0.3 \%$ Triton X-100 in PBS and then with $0.25 \%$ fetal bovine serum to block nonspecific immunoglobulin binding. The sections or cells were treated with the first antibodies at a dilution of $1: 100$ at $4^{\circ} \mathrm{C}$ overnight; the antibodies used were rabbit antibodies against histidine decarboxylase (HDC; Santa Cruz Biotechnology Inc.) and histamine (Abcam, Cambridge, UK), and goat antibodies against MC1R, MC5R, and mast cell protease 5 (Santa Cruz Biotechnology Inc.). After washing, the preparations were incubated with Alexa Fluor 555-conjugated anti-goat IgG (Life Technologies) for 1 hour at room temperature. The sections and cells were rinsed in PBS after each treatment. Finally, the sections and cells were counterstained with DAPI. Immunofluorescence was visualized with the use of a laser 
A

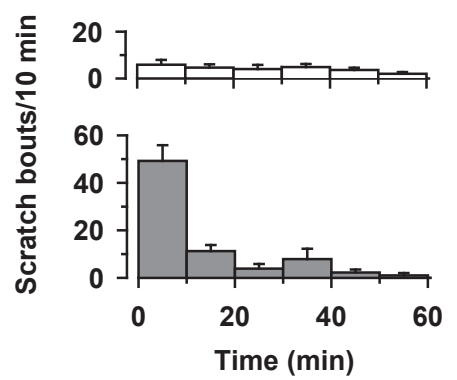

B

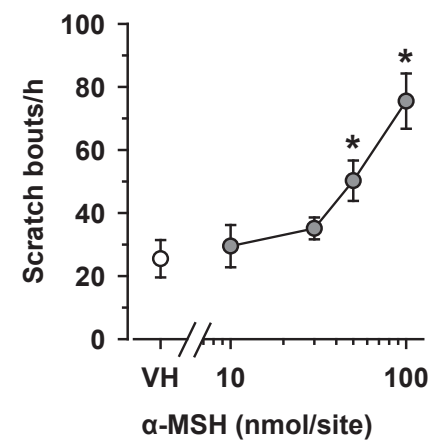

C

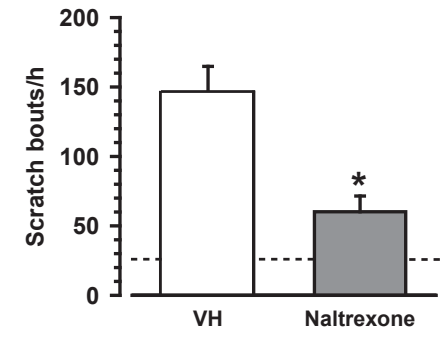

Figure 1 Scratching after intradermal injections of $\alpha$-MSH in ICR mice and effects of naltrexone. Hind-paw scratching of the injection site was counted for 1 hour after intradermal injection of $\alpha$-MSH or the VH1. A: Time course of scratching after VH1 (upper panel) and $\alpha$-MSH (100 nmol/L per site; lower panel) injections. B: Dose-response curve for the scratching effects of $\alpha-\mathrm{MSH}$ and VH1. C: Naltrexone hydrochloride (1 mg/kg) or VH was injected subcutaneously 15 minutes before $\alpha$-MSH (100 nmol/L per site) injection. The dotted line represents the average value of scratching bouts after intradermal injection of VH1. Data are expressed as means \pm SEM. $n=2$ independent experiments (B); $n=8$ animals (C). ${ }^{*} P<0.05$ versus VH (B, Holm-Šidák multiple comparisons; C, Student's t-test). $\alpha$-MSH, $\alpha$-melanocyte-stimulating hormone; VH, vehicle.

scanning confocal microscope (Leica Microsystems, Tokyo, Japan) or a fluorescent microscope (Olympus Co., Tokyo, Japan). After scanning, the slide glass was washed with PBS. The skin section was stained with toluidine blue and observed with the use of light microscope (Olympus Co.).

For a portion of the immunostaining, we used the antibody preabsorbed with the antigen peptides as a negative control. The antigen peptides for HDC, MC1R, and MC5R were purchased from Santa Cruz Biotechnology, Inc. The preparation of the antibody preabsorbed with the antigen peptides was performed according to the manufacturer's protocol (Santa Cruz Biotechnology, Inc.).

\section{RT-PCR}

Total RNA was extracted from cultured Pam212 cells. The cell samples were lyzed with the TRIzol reagent (Invitrogen) for RNA preparation. Total RNA $(0.4 \mu \mathrm{g} / \mathrm{sample})$ was used for cDNA synthesis with oligo $(\mathrm{dT})_{16}$ primers and reverse transcriptase (Reverscript III; Wako Pure Chemical Industries Ltd.). cDNA was amplified with the use of the following primers: MC1R, 5'-GCCCACATGTTCACGAGAGC-3' (forward) and 5'-AGTTACCCTTTCTCCTGGCCC-3' (reverse); MC5R, 5'-AAATCCGATGCCAAGAAGTG-3' (forward) and 5'-GGTAGCGCAAGGCATAGAAG-3' (reverse); HDC, 5'-AGCACAAGCTGTCGTCCTTT-3' (forward) and 5'-GTGGATCACGAAGACCCTGT-3' (reverse). Glyceraldehyde 3-phosphate dehydrogenase was used as a positive control. The primers used for glyceraldehyde 3-phosphate dehydrogenase were 5'-ACCCAGAAGACTGTGGAT-3' (forward) and 5'-TCGTTGAGGGCAATGCCA- $3^{\prime}$ (reverse). The cycling conditions were 5 minutes at $94^{\circ} \mathrm{C}, 35$ cycles of 30 seconds at $94^{\circ} \mathrm{C}, 30$ seconds at $58^{\circ} \mathrm{C}$, and 30 seconds at $72^{\circ} \mathrm{C}$, and 7 minutes at $72^{\circ} \mathrm{C}$. After PCR, the amplified products were analyzed by $2 \%$ agarose gel electrophoresis.
A

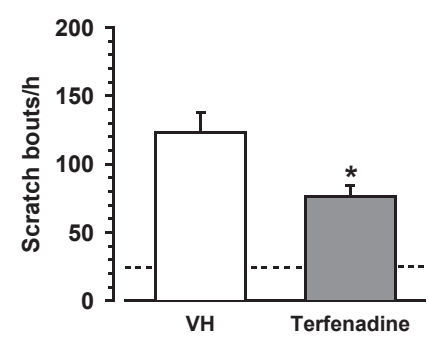

B

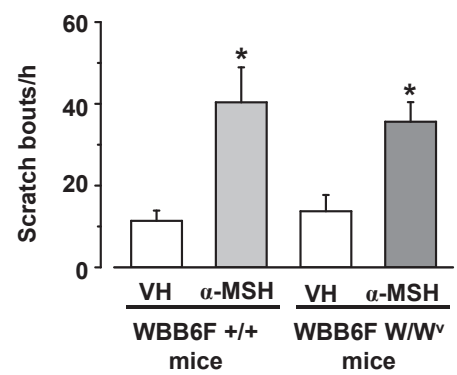

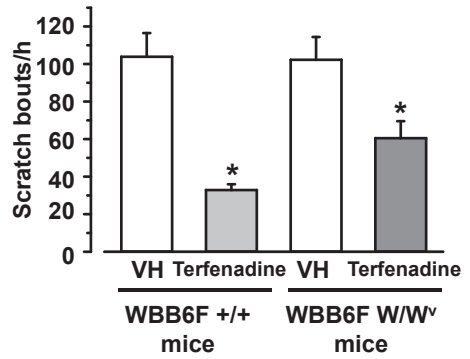

Figure 2 Effect of terfenadine and mast-cell deficiency on $\alpha$-MSH-induced scratching. Terfenadine $(30 \mathrm{mg} / \mathrm{kg})$ or VH1 was injected orally 30 minutes before $\alpha$-MSH (100 nmol/L per site) injection. Hind-paw scratching of the injection site was counted for 1 hour after intradermal injection of $\alpha-$ MSH or VH2. A: Effect of terfenadine on $\alpha$-MSH-induced scratching in ICR mice. The dotted line represents the average value of scratching bouts after intradermal injection

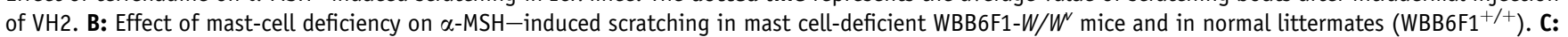
Effect of terfenadine on $\alpha-\mathrm{MSH}-$ induced scratching in WBB6F1-W/W and WBB6F1 $1^{+/+}$mice. Data are expressed as means \pm SEM. $n=7$ to 8 animals. ${ }^{*} P<0.05$ (A, Student's t-test; B and C, Holm-Šidák multiple comparisons). $\alpha$-MSH, $\alpha$-melanocyte-stimulating hormone; $\mathrm{VH}$, vehicle. 
A
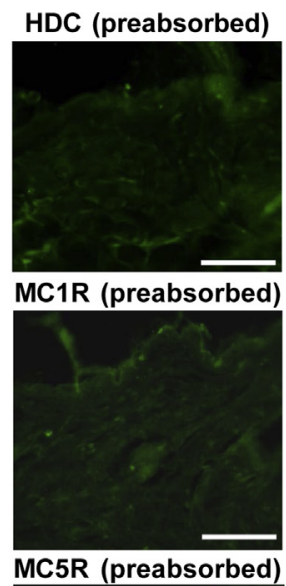

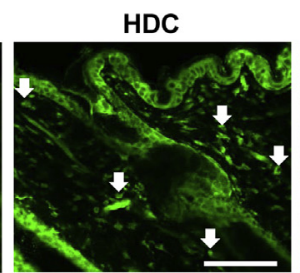

MC1R
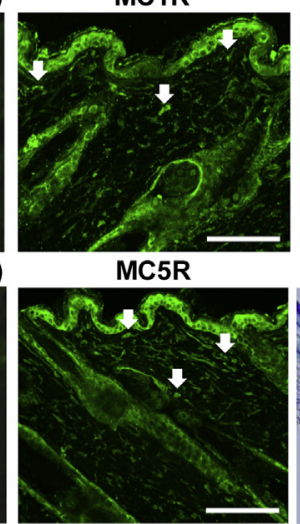

B
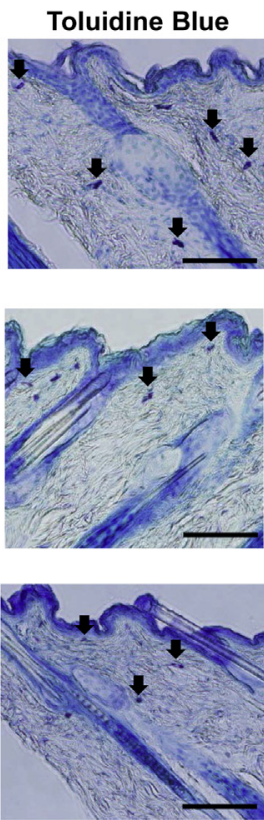

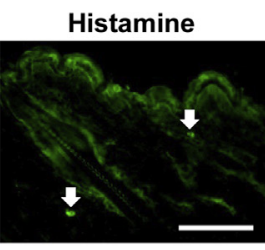

MCP-5
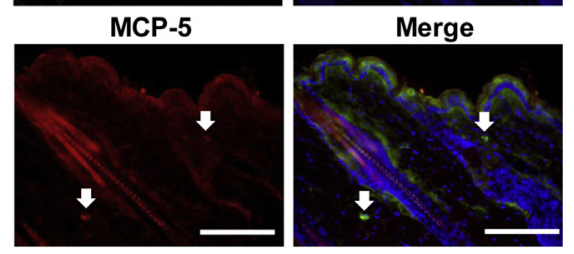

Figure 3 Cutaneous distribution of HDC, melanocortin receptors (MC1R and MC5R), and histamine in ICR mice. A: Center panels show HDC and melanocortin receptors (MC1R and MC5R) immunoreactivity in the skin of the ICR mice. Left panels show the images obtained with the antibody preabsorbed with the antigens for HDC, MC1R, and MC5R (negative control). Right panels show the light microscopy images for toluidine blue staining. B: Expression of histamine (green) and mast cell protease 5 (red). Arrows represent mast cells. Scale bar $=100 \mu \mathrm{m}$. HDC, histidine decarboxylase; MC1R, melanocortin 1 receptor; MC5R, melanocortin 5 receptor; $\mathrm{MCP}$, mast cell protease.

\section{Western Blot Analysis}

Proteins were extracted from cultured Pam 212 cells with a lysis buffer [20 mm Tris- $\mathrm{HCl}$ (pH 7.5), $137 \mathrm{~mm} \mathrm{NaCl}, 1 \%$ NP-40, $10 \%$ glycerol, $1 \mathrm{~mm}$ phenylmethyl sulfonyl fluoride, $10 \mu \mathrm{g} / \mathrm{mL}$ aprotinin, and $1 \mu \mathrm{g} / \mathrm{mL}$ leupeptin]. The protein lysates were denatured at $95^{\circ} \mathrm{C}$ for 5 minutes and were applied to an SDS-polyacrylamide gel for electrophoresis and transferred to nitrocellulose membranes. After blocking with $1 \%$ skim milk in PBS that contained $0.1 \%$ Tween 20 , the membrane was reacted with goat polyclonal anti-HDC, anti-MC1R, anti-MC5R, and anti- $\beta$-actin antibodies (dilution 1:1000 each), respectively, overnight at $4^{\circ} \mathrm{C}$. After washing with PBS that contained $0.1 \%$ Tween 20 , the membranes were incubated with horseradish peroxidase-labeled donkey anti-goat IgG antibody (dilution 1:1000; Bethyl Laboratories, Inc., Montgomery, TX) for 2 hours at room temperature. These membranes were then scanned with the lumino image analyzer Image Quant LAS-4000 (Fujifilm, Tokyo, Japan).

\section{Measurement of Histamine Released from Murine Cell} Line Pam212

$\alpha$-MSH $(200 \mu \mathrm{mol} / \mathrm{L})$ was dissolved in Opti-MEM, as a reaction medium, and applied to the cells. Five and 10 minutes later, the reaction medium was collected. In the experiments that used the cells treated with siRNA, SQ 22,536, or EGTA, the reaction medium was collected 5 minutes after $\alpha$-MSH application. The concentration of the released histamine was measured with the histamine enzyme immunoassay kit (Bertin Pharma, Montigny-le-Bretonneux, France) according to the manufacturer's recommendation. The protein of Pam 212 cells was extracted by the application of $1 \%$ Triton $\mathrm{X}-100$, and the concentration was measured by using protein assay reagent (Bio-Rad, Hercules, CA). The released histamine concentration in the reaction medium was normalized to the protein concentration of the Pam212 cells.

\section{Statistical Analysis}

All values are expressed as the means \pm SEM of the respective test or control group. Statistical significance was evaluated with either Student's $t$-test or Holm-Šidák multiple comparisons. $P<0.05$ was considered significant.

\section{Results}

\section{Behavioral Effects of $\alpha$-MSH}

An intradermal injection of $\alpha$-MSH (100 nmol/L per site) induced marked scratching of the injected site by the hind paws compared with the vehicle. The effect peaked in the initial 10-minute period and almost completely subsided within 60 minutes (Figure 1A). The administration of $\alpha$-MSH at intradermal doses of 10 to $100 \mathrm{nmol}$ per site elicited scratching in a dose-dependent manner (Figure 1B). In the 
A
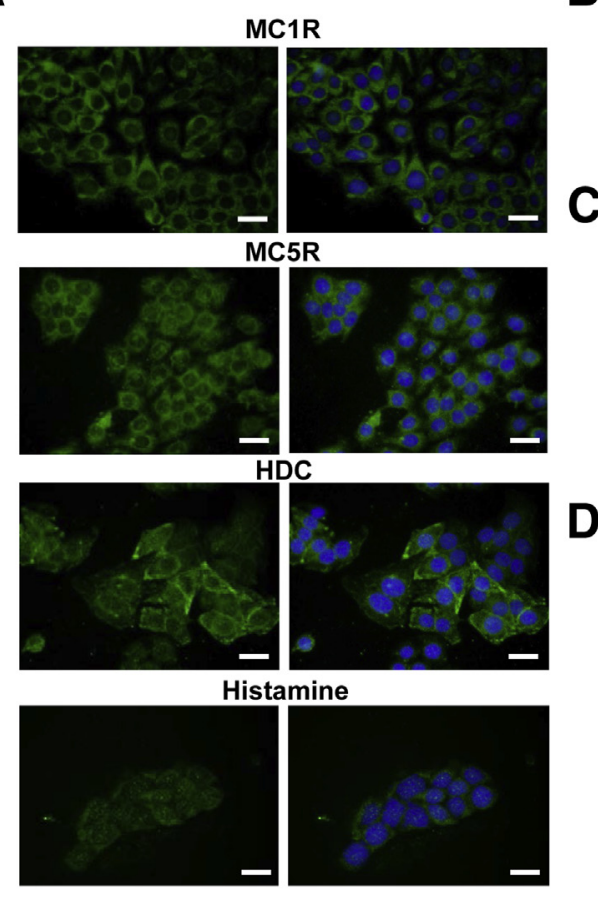

B
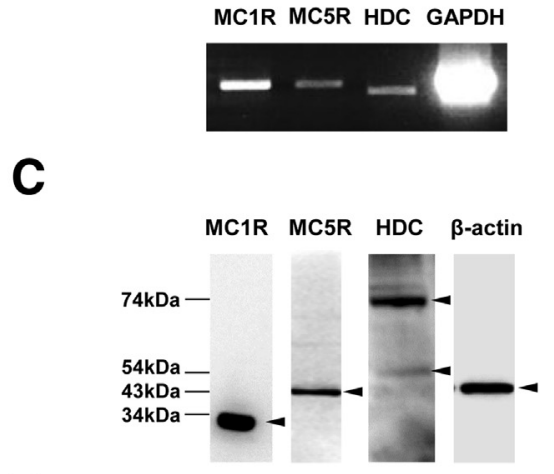

D

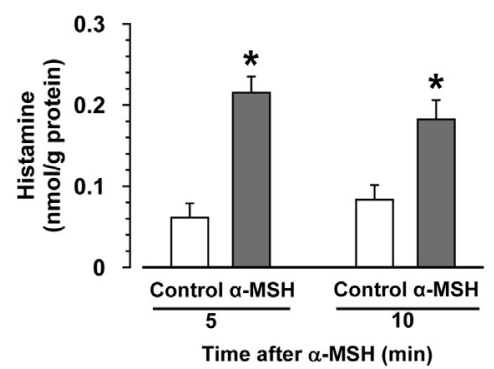

Figure 4 Expression of HDC, MC1R, MC5R, and histamine in murine keratinocyte cell line Pam212 and release of histamine after $\alpha$-MSH treatment. A: HDC, MC1R, MC5R, and histamine immunoreactivity in Pam212 cells. B and C: RT-PCR and a Western blot analysis show the expression of HDC MC1R, and MC5R in the Pam212 cells. Arrowheads indicate the protein levels of MC1R (34 kDa), MC5R (43 kDa), HDC (74 and $54 \mathrm{kDa}$ ), and $\beta$-actin (42 kDa). D: Release of histamine after $200 \mu \mathrm{mol} / \mathrm{L} \alpha-\mathrm{MSH}$ treatment. Data are expressed as means \pm SEM. $n=2$ independent experiments (B-D); $n=6$ wells (D). ${ }^{*} P<0.05$ versus culture medium only (Holm-Šidák multiple comparisons). Scale bar $=20 \mu \mathrm{m}$. GAPDH, glyceraldehyde 3-phosphate dehydrogenase; HDC, histidine decarboxylase; MC1R, melanocortin 1 receptor; MC5R, melanocortin 5 receptor; $\alpha-M S H$, $\alpha$-melanocyte-stimulating hormone. following in vivo experiments, a dose of $100 \mathrm{nmol}$ per site of $\alpha$-MSH was used.

\section{Effects of Various Agents on the $\alpha$-MSH-Induced Scratching}

Subcutaneous pretreatment with $1 \mathrm{mg} / \mathrm{kg}$ selective $\mu$-opioid receptor antagonist, naltrexone hydrochloride, ${ }^{15}$ inhibited the $\alpha$-MSH-induced scratching (Figure 1C). Oral pretreatment with $30 \mathrm{mg} / \mathrm{kg} \mathrm{H} \mathrm{H}_{1}$ histamine receptor antagonist, terfenadine, ${ }^{16}$ also suppressed the $\alpha$-MSH-induced scratching (Figure 2A).

\section{Effects of Mast Cell Deficiency on the $\alpha$-MSH-Induced Scratching}

An intradermal injection of $\alpha$-MSH elicited significant scratching in both mast cell-deficient mice (WBB6F1 W/W $W^{v}$ and their normal littermates $\left(\mathrm{WBB} 6 \mathrm{~F} 1^{+/+}\right)$, compared with vehicle-injected mice (Figure 2B). The number of scratches was almost the same between these mice. Interestingly, the administration of $30 \mathrm{mg} / \mathrm{kg} \mathrm{H} \mathrm{H}_{1}$ histamine receptor antagonist terfenadine significantly inhibited the $\alpha-\mathrm{MSH}-$ induced scratching in both mast cell-deficient mice (WBB6F1 $W / W^{v}$ ) and their normal littermates (WBB6F1 ${ }^{+/+}$), compared with vehicle-treated mice (Figure 2C).

\section{Distribution of HDC, MC1R, MC5R, and Histamine in Mouse Skin}

Immunohistochemical staining showed that HDC, MC1R, and MC5R were mainly expressed in both epidermal keratinocytes and dermal cells stained with toluidine blue (Figure 3A).
Histamine was similarly expressed in both epidermal keratinocytes and dermal cells seen by the immunoreactivity of mast cell protease 5 (Figure 3B).

Expression of HDC, MC1R, MC5R, and Histamine in the Mouse Keratinocyte Cell Line Pam212 Cells

Pam212 cells showed immunoreactivity for HDC, MC1R, MC5R, and histamine (Figure 4A). In addition, RT-PCR and Western blot analysis also showed the expression of HDC, MC1R, and MC5R in Pam212 cells (Figure 4, B and C).

\section{Release of Histamine from Pam212 Cells Stimulated with $\alpha$-MSH}

In the present in vivo study, an intradermal injection of $\alpha$-MSH $(100 \mathrm{nmol} / 50 \mu \mathrm{L}=2 \mathrm{mmol} / \mathrm{L})$ elicited scratching (Figure 1A). However, $\alpha$-MSH $(10 \mathrm{nmol} / 50 \mu \mathrm{L}=200$ $\mu \mathrm{mol} / \mathrm{L}$ ) led to a slight, but not significant, increase in scratching, compared with the vehicle-injected group (Figure 1B). Because $\alpha$-MSH acts directly on the cells in vitro, $\alpha-\mathrm{MSH}$ was administered at a final concentration of $200 \mu \mathrm{mol} / \mathrm{L}$ in these cell culture studies. Because $\alpha$-MSH-induced scratching was observed mainly during the initial 10-minute period, the release of histamine was measured for 10 minutes after $\alpha$-MSH stimulation. Treatment with $200 \mu \mathrm{mol} / \mathrm{L} \alpha$-MSH significantly increased the concentration of histamine in the culture medium 5 and 10 minutes after the application of $\alpha$-MSH, compared with the medium of cells treated without $\alpha-\mathrm{MSH}$ (Figure 4D). The effect peaked after the initial 5-minute period (Figure 4D). 


\section{A}

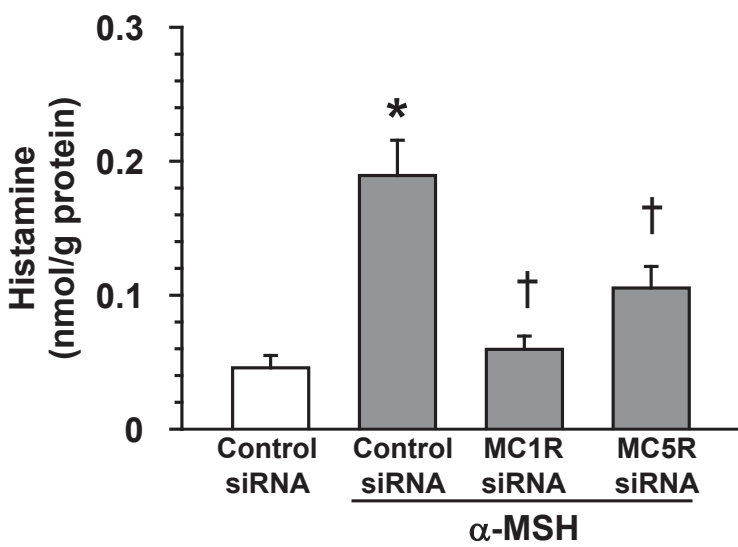

B

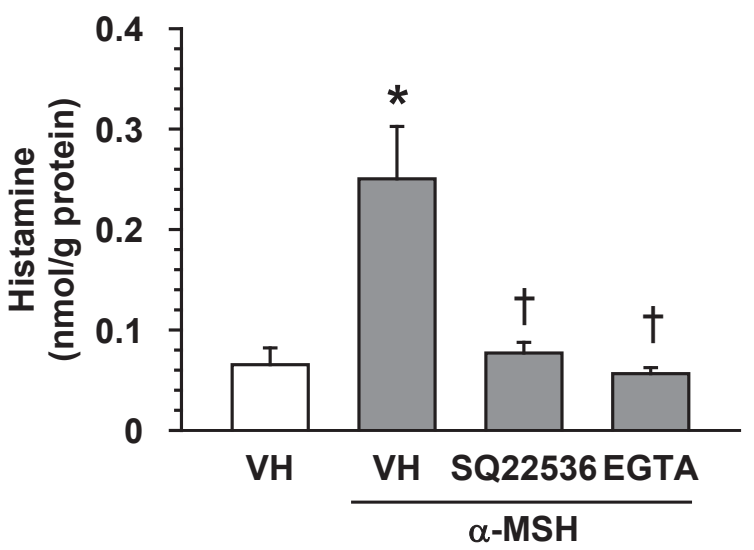

Figure 5 Effects of siRNA on MC1R, MC5R, and cell signaling-regulated agents. A: $\alpha$-MSH $(200 \mu \mathrm{mol} / \mathrm{L})$ was applied to Pam212 cells treated with siRNA for MC1R or MC5R or nonspecific control siRNA. B: SQ 22,536 (100 $\mu \mathrm{mol} / \mathrm{L}), \mathrm{EGTA}(1 \mathrm{mmol} / \mathrm{L})$, or VH ( $0.1 \%$ dimethyl sulfoxide) was treated 30 minutes before $200 \mu \mathrm{mol} / \mathrm{L} \alpha-\mathrm{MSH}$ application. The amount of histamine in the reaction medium was measured 5 minutes after $200 \mu \mathrm{mol} / \mathrm{L} \alpha$-MSH application with the use of an enzyme immunoassay kit and was normalized to the amount of protein in the cells. Data are expressed as means \pm SEM. $n=6$ wells. ${ }^{*} P<0.05$ versus the reaction medium that contained the Pam212 cells treated with control siRNA or VH in the Pam212 cells; ${ }^{\dagger} P<0.05$ versus the reaction medium applied with $\alpha$-MSH in the Pam212 cells treated with control siRNA or VH (Holm-Šidák multiple comparisons). MC1R, melanocortin 1 receptor; MC5R, melanocortin 5 receptor; $\alpha-M S H$, $\alpha$-melanocyte-stimulating hormone; $\mathrm{VH}$, vehicle.

$\alpha$-MSH did not elicit the release of histamine in the cells treated with MC1R or MC5R siRNA (Figure 5A and Supplemental Figure S1). In addition, $100 \mu \mathrm{mol} / \mathrm{L}$ adenylyl cyclase inhibitor SQ 22,536 ${ }^{17}$ (Supplemental Figure S2 ${ }^{18}$ ) and $1 \mathrm{mmol} / \mathrm{L}$ calcium chelator EGTA ${ }^{19}$ also inhibited the release of histamine induced by $\alpha$-MSH (Figure 5B).

\section{Discussion}

Intradermal injections of $\alpha$-MSH into the rostral part of the skin elicited hind-paw scratching of the injection site in mice. The $\alpha-\mathrm{MSH}-$ induced scratching was inhibited by treatment with the $\mu$-opioid receptor antagonist naltrexone. It was reported that $\mu$-opioid receptor antagonists inhibit scratching induced by pruritogens ${ }^{15,20-22}$ and dermatoses in rodents ${ }^{16,23-25}$ and itching and scratching in humans with pruritic diseases. ${ }^{26-29}$ However, $\mu$-opioid receptor antagonists attenuate itch-related but not pain-related behavior. ${ }^{30-33}$ Taking into account these findings in humans and rodents, our results showing that the action of $\alpha-\mathrm{MSH}$ was inhibited by $\mu$-opioid receptor antagonists are consistent with the idea that $\alpha$-MSH-induced scratching is because of pruritogenic, but not algesiogenic, stimulation of the treated skin.

In this study, we also found that $\alpha$-MSH-induced scratching was inhibited partially, but significantly, by treatment with a $\mathrm{H}_{1}$ histamine receptor antagonist terfenadine at a dose that almost completely inhibited the histamine-induced scratching, ${ }^{16}$ suggesting that histamine is involved in $\alpha$-MSH-induced scratching. $\alpha-\mathrm{MSH}$ is involved in the pigmentation due to sunburn, ${ }^{10,11}$ hemodialysis, ${ }^{12}$ and wound repair. ${ }^{13}$ Antihistamines are effective for treating pruritus in the patients with the above-mentioned causes of pigmentation. ${ }^{1,34,35}$ Therefore, these reports support our findings.

It is well known that histamine is mainly produced by the mast cells in skin. However, in this study, $\alpha-\mathrm{MSH}$ elicited scratching in both mast cell-deficient mice and their normal littermates. Interestingly, terfenadine inhibited the $\alpha-\mathrm{MSH}-$ induced scratching in both the mast celldeficient mice and normal littermates. Taken together, these findings suggest that histamine is involved in the $\alpha-\mathrm{MSH}-$ induced scratching, and mast cells may not contribute to the release of histamine involved in this scratching.

HDC is a key enzyme in the biosynthesis of histamine. ${ }^{36}$ In this study, we observed the immunoreactivity to HDC and histamine not only in mast cells but also keratinocytes in mouse skin. In addition, the mouse keratinocyte cell line, Pam212, also showed the immunoreactivity to HDC and histamine. Human epidermal cells and keratinocytes also express HDC. ${ }^{37,38}$ We also detected low (54 kDa)- and high (74 kDa)-molecular weight protein bands of HDC in the Pam212 cells; 74-kDa HDC is a precursor protein that exhibits a low enzyme activity. Furthermore, 74-kDa HDC is post-translationally cleaved to a $53-$ to $55-\mathrm{kDa}$ species, and histamine is synthesized mainly by a $53-$ to $55-\mathrm{kDa}$ HDC. ${ }^{36}$ Treatment with $\alpha$-MSH induced histamine release from Pam 212 cells. Thus, keratinocytes may play an important role in the production of histamine, and this appears to be related to the $\alpha$-MSH-induced scratching.

In mast cells, histamine is stored in granules and is released by several types of stimuli (such as immune reactions). ${ }^{36}$ Macrophages also express HDC and spontaneously release histamine without it being stored intracellularly (these cells do not contain histamine-storing granules). ${ }^{36,39}$ Because keratinocytes also do not have histamine-storing granules, the histamine would be released immediately after its biosynthesis. In this study, keratinocytes slightly produced histamine. A recent report has shown histamine induces proliferation in keratinocytes through $\mathrm{H}_{4}$ histamine 
receptors. ${ }^{40}$ Thus, in a normal skin condition, histamine is involved in the proliferation in keratinocyte as one of the actions. However, overproduction of histamine induced by several stimulations, such as $\alpha$-MSH (present study) and surfactant, ${ }^{37}$ may be involved in the induction of itching.

The application of $\alpha$-MSH induced the release of histamine from the mouse keratinocytes cell line Pam212 in this study. Pam 212 cells also expressed MC1R and MC5R receptors. The cells treated with siRNA for MC1R and MC5R showed no release of histamine after stimulation with $\alpha-\mathrm{MSH}$, suggesting that at least MC1R and MC5R are involved in $\alpha-\mathrm{MSH}-$ induced histamine release. The mechanism underlying the production of histamine after the stimulation with $\alpha$-MSH is still unclear. Miyazaki et $\mathrm{al}^{41}$ have shown that the activity of HDC was increased by $N^{6}, O^{2}$-dibutyryl cAMP plus $\mathrm{Ca}^{2+}$ ionophore A23187. The activation of MC1R and MC5R receptors by $\alpha$-MSH increases both the production of $\mathrm{cAMP}^{8}$ and the intracellular-free $\mathrm{Ca}^{2+}$ concentration. ${ }^{9}$ Here, $\alpha$-MSH-induced histamine release was inhibited by the adenylyl cyclase inhibitor, which suppressed cAMP production and a calcium chelator. Therefore, our findings suggest that increased cAMP (Supplemental Figure S2) and intracellular calcium levels may be involved in the production of histamine through melanocortin receptors.

In the present study, the treatment with a $\mathrm{H}_{1}$ histamine receptor antagonist did not completely inhibit the $\alpha$-MSHinduced scratching. The cutaneous distribution of melanocortin receptors (MC1R, MC3R, MC4R, and MC5R) for $\alpha-\mathrm{MSH}$ is not fully understood. It is known that in the mouse dorsal root ganglia, MC1R, MC3R, and MC4R, but not MC5R, are expressed, ${ }^{42}$ suggesting that MC1R, MC3R, and MC4R are presented on primary afferents. Thus, $\alpha-\mathrm{MSH}$ may act directly via primary afferents to induce itch. Recently, it was reported that there are two main types of itch-related primary afferents; $\mathrm{H}_{1}$ histamine receptorexpressing neurons and mas-related G-coupled protein receptor A3-expressing neurons. ${ }^{43}$ A future study should be performed to determine the distribution of melanocortin receptors in these primary afferents.

\section{Conclusion}

In conclusion, $\alpha-\mathrm{MSH}$ is an itch mediator, and the histamine released from keratinocytes, but not mast cells, may be involved in this $\alpha$-MSH-induced itching.

\section{Supplemental Data}

Supplemental material for this article can be found at http://dx.doi.org/10.1016/j.ajpath.2015.07.015.

\section{References}

1. Han A, Maibach HI: Management of acute sunburn. Am J Clin Dermatol 2004, 5:39-47
2. Gilchrest BA, Soter NA, Stoff JS, Mihm MC Jr: The human sunburn reaction: histologic and biological studies. Am Acad Dermatol 1981, 5: 411-422

3. Paul J: Characteristics of chronic wounds that itch. Adv Skin Wound Care 2013, 26:320-332

4. Slominski A, Tobin DJ, Shibahara S, Wortsman J: Melanin pigmentation in mammalian skin and its hormonal regulation. Physiol Rev 2004, 84:1155-1228

5. Slominski A, Wortsman J, Luger T, Paus R, Solomon S: Corticotropin releasing hormone and proopiomelanocortin involvement in the cutaneous response to stress. Physiol Rev 2000, 80:979-1020

6. Slominski AT, Zmijewski MA, Zbytek B, Tobin DJ, Theoharides TC, Rivier J: Key role of CRF in the skin stress response system. Endocr Rev 2013, 34:827-884

7. Slominski AT, Zmijewski MA, Skobowiat C, Zbytek B, Slominski RM, Steketee JD: Sensing the environment: regulation of local and global homeostasis by the skin's neuroendocrine system. Adv Anat Embryol Cell Biol 2012, 212:v. vii, 1-115

8. Cooray SN, Clark AJ: Melanocortin receptors and their accessory proteins. Mol Cell Endocrinol 2011, 331:215-221

9. Mountjoy KG, Kong PL, Taylor JA, Willard DH, Wilkison WO: Melanocortin receptor-mediated mobilization of intracellular free calcium in HEK293 cells. Physiol Genomics 2011, 5:11-19

10. Böhm M, Luger TA, Tobin DJ, García-Borrón JC: Melanocortin receptor ligands: new horizons for skin biology and clinical dermatology. J Invest Dermatol 2006, 126:1966-1975

11. Oren M, Bartek J: The sunny side of p53. Cell 2007, 128:826-828

12. Airaghi L, Garofalo L, Cutuli MG, Delgado R, Carlin A, Demitri MT, Badalamenti S, Graziani G, Lipton JM, Catania A: Plasma concentrations of alpha-melanocyte-stimulating hormone are elevated in patients on chronic haemodialysis. Nephrol Dial Transplant 2000, 15:1212-1216

13. Muffley LA, Zhu KQ, Engrav LH, Gibran NS, Hocking AM: Spatial and temporal localization of the melanocortin 1 receptor and its ligand $\alpha$-melanocyte-stimulating hormone during cutaneous wound repair. J Histochem Cytochem 2011, 59:278-288

14. Kuraishi Y, Nagasawa T, Hayashi K, Satoh M: Scratching behavior induced by pruritogenic but not algesiogenic agents in mice. Eur J Pharmacol 1995, 275:229-233

15. Andoh T, Kuwazono T, Lee JB, Kuraishi Y: Gastrin-releasing peptide induces itch-related responses through mast cell degranulation in mice. Peptides 2011, 32:2098-2103

16. Ohtsuka E, Kawai S, Ichikawa T, Nojima H, Kitagawa K, Shirai Y, Kamimura K, Kuraishi Y: Roles of mast cells and histamine in mosquito bite-induced allergic itch-associated responses in mice. Jpn J Pharmacol 2001, 86:97-105

17. Turcato S, Clapp LH: Effects of the adenylyl cyclase inhibitor SQ22536 on iloprost-induced vasorelaxation and cyclic AMP elevation in isolated guinea-pig aorta. Br J Pharmacol 1999, 126:845-847

18. Andoh T, Kuraishi Y: Antipruritic mechanisms of topical E6005, a phosphodiesterase 4 inhibitor: inhibition of responses to proteinaseactivated receptor 2 stimulation mediated by increase in intracellular cyclic AMP. J Dermatol Sci 2014, 76:206-213

19. Sun FC, Shyu HY, Lee MS, Lee MS, Lai YK: Involvement of calciummediated reactive oxygen species in inductive GRP78 expression by geldanamycin in 9L rat brain tumor cells. Int J Mol Sci 2013, 14: 19169-19185

20. Andoh T, Nagasawa T, Satoh M, Kuraishi Y: Substance P induction of itch-associated response mediated by cutaneous NK1 tachykinin receptors in mice. J Pharmacol Exp Ther 1998, 286:1140-1145

21. Andoh T, Saito A, Kuraishi Y: Leukotriene B(4) mediates sphingosylphosphorylcholine-induced itch-associated responses in mouse skin. J Invest Dermatol 2009, 129:2854-2860

22. Yamaguchi T, Nagasawa T, Satoh M, Kuraishi Y: Itch-associated response induced by intradermal serotonin through 5-HT2 receptors in mice. Neurosci Res 1999, 35:77-83

23. Yamaguchi T, Maekawa T, Nishikawa Y, Nojima H, Kaneko M, Kawakita T, Miyamoto T, Kuraishi Y: Characterization of itch-associated 
responses of NC mice with mite-induced chronic dermatitis. J Dermatol Sci 2001, 25:20-28

24. Miyamoto T, Nojima H, Shinkado T, Nakahashi T, Kuraishi Y: Itchassociated response induced by experimental dry skin in mice. Jpn J Pharmacol 2002, 88:285-292

25. Fujii M, Nabe T, Tomozawa J, Kohno S: Involvement of skin barrier dysfunction in itch-related scratching in special diet-fed hairless mice. Eur J Pharmacol 2006, 530:152-156

26. Bernstein JE, Swift R: Relief of intractable pruritus with naloxone. Arch Dermatol 1979, 115:1366-1367

27. Monroe EW: Efficacy and safety of nalmefene in patients with severe pruritus caused by chronic urticaria and atopic dermatitis. J Am Acad Dermatol 1989, 21:135-136

28. Bergasa NV, Alling DW, Talbot TL, Swain MG, Yurdaydin C, Turner ML, Schmitt JM, Walker EC, Jones EA: Effects of naloxone infusions in patients with the pruritus of cholestasis. A double-blind, randomized, controlled trial. Ann Intern Med 1995, 123:161-167

29. Bergasa NV, Talbot TL, Alling DW, Schmitt JM, Walker EC, Baker BL, Korenman JC, Park Y, Hoofnagle JH, Jones EA: A controlled trial of naloxone infusions for the pruritus of chronic cholestasis. Gastroenterology 1992, 102:544-549

30. Maekawa T, Yamaguchi-Miyamoto T, Nojima H, Kuraishi Y: Effects of naltrexone on spontaneous itch-associated responses in NC mice with chronic dermatitis. Jpn J Pharmacol 2002, 90:193-196

31. Nojima H, Simons CT, Cuellar JM, Carstens MI, Moore JA, Carstens E: Opioid modulation of scratching and spinal c-fos expression evoked by intradermal serotonin. J Neurosci 2003, 23: 10784-10790

32. Akiyama T, Carstens MI, Carstens E: Differential itch- and painrelated behavioral responses and $\mu$-opoid modulation in mice. Acta Derm Venereol 2010, 90:575-581

33. Gotoh Y, Andoh T, Kuraishi Y: Noradrenergic regulation of itch transmission in the spinal cord mediated by $\alpha$-adrenoceptors. Neuropharmacology 2011, 61:825-831
34. Matsui C, Ida M, Hamada M, Morohashi M, Hasegawa M: Effects of azelastine on pruritus and plasma histamine levels in hemodialysis patients. Int J Dermatol 1994, 33:868-871

35. Matheson JD, Clayton J, Muller MJ: The reduction of itch during burn wound healing. J Burn Care Rehabil 2001, 22:76-81

36. Ichikawa A, Sugimoto Y, Tanaka S: Molecular biology of histidine decarboxylase and prostaglandin receptors. Proc Jpn Acad Ser B Phys Biol Sci 2010, 86:848-866

37. Inami Y, Andoh T, Sasaki A, Kuraishi Y: Topical surfactant-induced pruritus: involvement of histamine released from epidermal keratinocytes. J Pharmacol Exp Ther 2013, 344:459-466

38. Gutowska-Owsiak D, Greenwald L, Watson C, Selvakumar TA, Wang X, Ogg GS: The histamine-synthesizing enzyme histidine decarboxylase is upregulated by keratinocytes in atopic skin. Br J Dermatol 2014, 171:771-778

39. Hirasawa N, Murakami A, Ohuchi K: Expression of 74-kDa histidine decarboxylase protein in a macrophage-like cell line RAW 264.7 and inhibition by dexamethasone. Eur J Pharmacol 2001, 418:23-28

40. Glatzer F, Gschwandtner M, Ehling S, Rossbach K, Janik K, Klos A, Bäumer W, Kietzmann M, Werfel T, Gutzmer R: Histamine induces proliferation in keratinocytes from patients with atopic dermatitis through the histamine 4 receptor. J Allergy Clin Immunol 2013, 132: $1358-1367$

41. Miyazaki T, Ohgoh M, Ohmori E, Yamamoto J, Emoto S, Yatsunami K, Ichikawa A: Synergistic effects of cyclic AMP and $\mathrm{Ca} 2+$ ionophore A23187 on de novo synthesis of histidine decarboxylase in mastocytoma P-815 cells. Biochim Biophys Acta 1992, 1133:179-186

42. Tanabe K, Gamo K, Aoki S, Wada K, Kiyama H: Melanocortin receptor 4 is induced in nerve-injured motor and sensory neurons of mouse. J Neurochem 2007, 101:1145-1152

43. Akiyama T, Carstens E: Neural processing of itch. Neuroscience 2013 250:697-714 